\title{
The Oyster Culture of the Ancient Romans.
}

\author{
By \\ R. T. Günther, M.A., \\ Fellow of Magdalen College, Oxford. \\ With Plate $I$.
}

WHILE engaged in the examination of some vase pictures which have been stated to represent certain parts of the shores of the Bay of Pozzuoli as it existed in Roman times, I was struck by two drawings of Roman oyster culture grounds, or ostrearia, which seem to me to be of considerable interest, not only as affording us direct information concerning the method of oyster culture employed by the Romans in the neighbourhood of Baiæ, but also because they show clearly that that method was the same as the one which still survives and is still carried on, in common with so many other Roman customs in the same locality, exactly as it was nearly two thousand years ago.

Our knowledge of the methods pursued by the Romans in the cultivation of oysters is derived from two sources. In the first place we meet with scattered allusions to oysters and their cultivation in many classical authors; and secondly, there are still preserved to us certain vases decorated with views of the apparatus employed in oyster culture.

Although passages alluding to oysters are fairly numerous, Latin authors seem to have found their gastronomic qualities a more attractive theme than their natural history. Some, however, surprise us with the close and careful observation displayed by their remarks.

The credit of having been the first to lay out artificial oyster beds is commonly given to C. Sergius Orata. Orata was Praetor in 97 B.c., and was one of the most noted connoisseurs in the matter of oysters in his time. We read in Valerius Maximus that he closed the Lucrine Lake with extensive and lofty buildings, in order that the molluses (conchylia) might always be obtainable in a fresh condition. The works undertaken by Orata were evidently necessary to preserve the tranquillity of the waters of the oyster grounds, because it is probable 
that in stormy weather the waves rolled right into the lake from the sea (Strabo). It is further recorded that Orata became involved in a lawsuit with one Considius, who held that the Lucrine waters had been leased to him by the State, whose property they really were.

Notwithstanding his lawsuit he derived, writes Pliny, great profit from the oysters which he grew in his "ostrearum vivarium," and which he advertised as the finest obtainable. It must be remembered that at that time Britain had not begun to supply the Roman market with the much-praised Rutupian* oysters.

In Pliny's day, oysters were brought by sea from Brundusium to the Lucrine, where they were fattened after their long voyage. Pliny unfortunately gives no details which might enable us to form some opinion of what an "ostrearum vivarium" was like, although he has plenty to say about the conditions favourable to their growth. $\mathrm{He}$ states that they like the fresh water of streams falling into the sea; in the open sea they are small and rare. They grow best at the beginning of summer, wherever the sunlight beats upon the bottom. If they cannot be reached by the sun's rays they grow more slowly and eat little for sadness. The best are found on firm ground, on rocks, not on sand or mud. They are not tolerant of being transplanted to other waters.

The only passage with which I am acquainted that may be construed as referring to the artificial cultivation of oysters on ropes, which will be described in detail below, occurs in the comparatively late author Ausonius, who flourished in the latter half of the fourth century A.D. Ausonius writes of oysters, quae Baianis pendent fluitantia palis. This to my mind means that at Baiæ the oysters hang swaying about in the waves on the stakes-an interpretation which agrees perfectly with the vase drawings to be described. Ausonius certainly could not have applied the word fluitantia to oysters lying immovable on the bottom of the sea.

Owing to the absence of any detailed description of artificial oyster cultivation as practised by the Romans, the two vase pictures have a unique archæological interest, and constitute the only real foundation for our knowledge of Roman oyster culture.

One representation (Fig. 1) occurs upon a glass vase, which was found at Piombino, the ancient Populonia, and was figured and described by Domenico Sestini, when it formed part of the collection of the Grand Duchess of Tuscany, Princess of Lucca di Piombino. The vase is almost globular, with a narrow tubular neck. Its height is $25 \mathrm{~cm}$; widest diameter $13 \mathrm{~cm}$. The lower globular portion of the vase is decorated with a scene, which has been identified with the coast 
between Puteoli and Baiæ, as it existed in Roman times. It is not impossible that both this vase and others like it were sold at Roman watering-places to the visitors as mementoes of their holiday, just as similar topographical crockery is sold at our own seaside resorts to our more sentimental contemporaries.

The Piombino vase bears a panoramic view of the chief buildings along a coast line. At one end of the picture is a pier carried on four arches jutting out over the water. Upon the pier are two columns, with birds, inscribed PILAE, and two arches bearing four sea-horses. At the land end is a building with four gables, a type very common in Pompeian frescoes. Then follow two large buildings, perhaps built on piles, and connected by a bridge beneath which are the ostriaria. At the sides of the two large buildings and also behind the ostriaria are indications of waves. The vase bears the following inscription :-

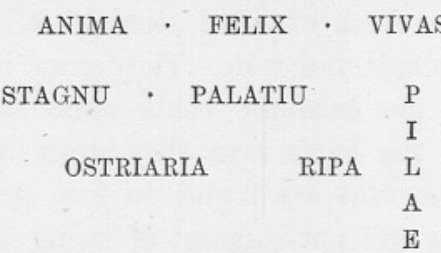

If the scene be really a representation of a portion of the Bay of Bair and of the pier of Puteoli, the sTAGNU referred to must be the Lucrine Lake.

The other vase (Figs. 2 and 3 ) is smaller, being less than half as high as the Piombino vase. It was originally described by De Rossi some forty years after Sestini had published the first, and is now in the Museo Borgiano di Propaganda Fede at Rome. It bears the inscription :-

\section{MEMORIAE - FELICISSIMAE $\cdot$ FILIAE}

FAROS ' STAGNU ' NERONIS ' OSTRIARIA ' STAGNU ' SILVA ' BAIAE.

Beneath the inscription are depicted several buildings, to the left of which is a reclining female figure holding two palm-branches in her right hand, and supposed by De Rossi to impersonate Baiæ.

To the right of this allegorical figure follow drawings of the objects specified in the inscription. The lighthouse (FAROS), pond or marsh (STAGNU(M) NeRonis), a wood (SILVA), and two buildings of similar architecture, with oyster-culture (OSTRIARIA) in between, are all represented.

The exact localisation of the scene is not an easy matter. Authorities are not agreed on the question whether the bit of coast lies to the south or east of Baiæ, nor even as to whether the view has been sketched from the sea or from the land. Those who support the last theory base their conviction on the fact that there are lines indicated between 
the houses, which they believe to represent waves of the sea as viewed by a spectator looking seawards. According to this theory the scene would have been situated to the south of Baiæ. The lighthouse (FAROS) might have been built on the site of the Fortino la Tenaglia, just beneath the hill on which Toledo's castle now stands; and the oyster-culture ground (OSTRIARIA) might have been in the shallows between the Fortino la Tenaglia and Baiæ, where at the present day from a boat many ruined walls can be seen below the clear water. On the other hand, it may be urged that if indeed the lines seen between the houses were meant to indicate water and not to be purely decorative, they might with equal truth represent the ripples of the Lucrine Lake seen from the sea, and their obviously artistic effect might have induced the artist to fill up his background with similar lines all round the vase.

Be the scene where it may, there can be no doubt that here we have a contemporary representation of Roman oyster cultivation not far from Baiæ.

Before proceeding to describe the ancient system of cultivation, a brief sketch of the modern system may facilitate the interpretation of the details shown none too clearly in the vase drawings. The method of culture employed at the present day in the Lucrine Lake is a method of hanging culture, as opposed to oyster culture in beds on the bottom.

The oysters are attached to coarse ropes, of loosely-twisted or plaited spartum grass, by being thrust between the strands (Fig. 6). These ropes, called pergolari at Taranto, are hung in the water from other ropes which are stretched horizontally between stakes driven into the mud at the bottom of the shallow lake. The tops of the stakes, and the horizontal ropes connecting them, are usually conspicuous objects on the surface of the water (Fig. 4). In the Mare piccolo, or inner harbour of Taranto, and in Lake Fusaro* (Fig. 5), a similar method of culture obtains. At Taranto the horizontal ropes are arranged so as to enclose quadrangular spaces, which are known as sciaje.

If we now turn to the OSTRIARIA as depicted on the vases, we find that the oysters and pergolari are shown as well as the perpendicular stakes, but that the modern horizontal ropes are replaced by more solid cross poles of wood. The ropes (pergolari) used for suspending the

* For a description of the oyster culture of Lake Fusaro, see Coste's Voyage d'exploration sur le Littoral de la France et de l'Italie. Although he makes no statement to that effect, Coste's illustrations (cf. Figs. 9-12) would lead one to suppose that the round objects hanging from the framework of the Roman ostrearia were intended to be baskets of oysters similar to those in use at the present day, both in Lake Fusaro and in the Lucrine, in addition to the ropes of the larger oysters. This interpretation may apply to the Piombino vase-picture, although even there the ropes project beyond the round objects, but does not, I think, agree with the Borgiano vase-picture so well as the one advanced above. My thanks are due to Mr. E. J. Allen for drawing my attention to Coste's memoir. 
oysters were evidently of a very rough make, to judge from the inequalities represented in Fig. 1.

The structure of the framework is rather difficult to make out. The drawings were apparently intended to show both the front elevation and the top view of the framework. In the Borgiano vase (Fig. 2) the framework is quite regular, and consists of four bars crossing five others at right angles (cf. the sciaje of Taranto). At the intersection of the bars a number of lines are drawn which may possibly represent either pegs or cord lashings used to fix or tie the bars together. The horizontal framework was supported by a number of vertical posts. Of these four are represented, and between them are shown three ropes with three oysters each. On the right-hand side is another similar rope of oysters, and above it two bars crossing, which were probably used to strengthen the fabric.

On the Piombino vase (Fig. 1) the picture of the ostrearium probably represents a similar view. The ostrearium lay between two houses and under a bridge-an arrangement analogous to that of the oyster cultivation of Lake Fusaro, accidentally shown in a photograph taken by myself (Fig. 5). Here, too, the end of the bridge abuts on an isolated building, the pleasure-house constructed by Ferdinand I. (not shown in Fig. 5). The poles for the oysters may be seen projecting above the water both beyond and under the bridge. In the Piombino vase the cross-bars of the framework are not arranged with such regularity as on the Borgiano vase.

In conclusion, the object of the present communication is to demonstrate that the only type of artificial oyster culture of the ancient Romans, of which we have an adequate knowledge, was the method of hanging rope culture, which still continues to exist at the the same spot, viz. the Lucrine Lake and its neighbourhood, and in an almost identical manner. Even the importation of oysters into the Lucrine is similar. At the present time they are brought from Taranto. In the days of the Romans, according to Pliny, they were imported from Brundusium.

Ausonius, D. M.-Epistolae, ix. 30.

\section{REFERENCES.}

Beloch, J.-Campanien. Breslau. 1890.

Coste, P.-Voyage d'Exploration sur le Littoral de la France et de l'Italie. Deuxième Edition. Paris, 1861.

Maximus, C. Valerius.-Lib. ix. 1.

Plinius, C.--Historia Naturalis. Lib. ix. 54 and 79 ; lib. xxxii, 21.

Rossi, G. B. de.-Topografia delle spiagge di Baja graffita sopra due vasi di vetro. Bulletino Archeologico Napolitano, n.s. I., No. 17, tav. ix, 1853.

Servius, M.-Commentarius in Verg. Georg. ii. 161.

Sestini, D.-Illustrazione d'un vaso antico di vetro ritrovato in un sepolcro presso l'antica Populonia. Firenze. 1812. 


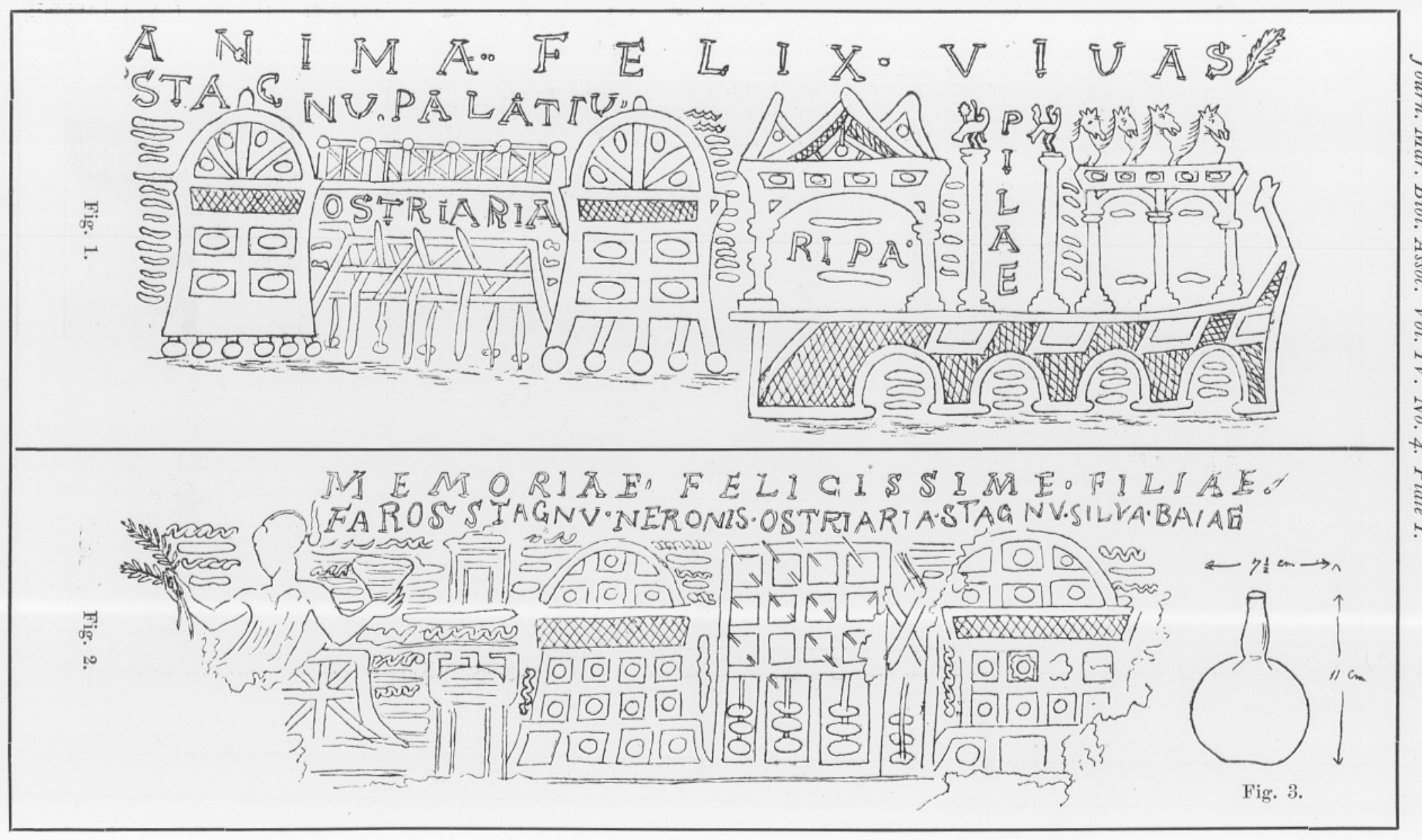




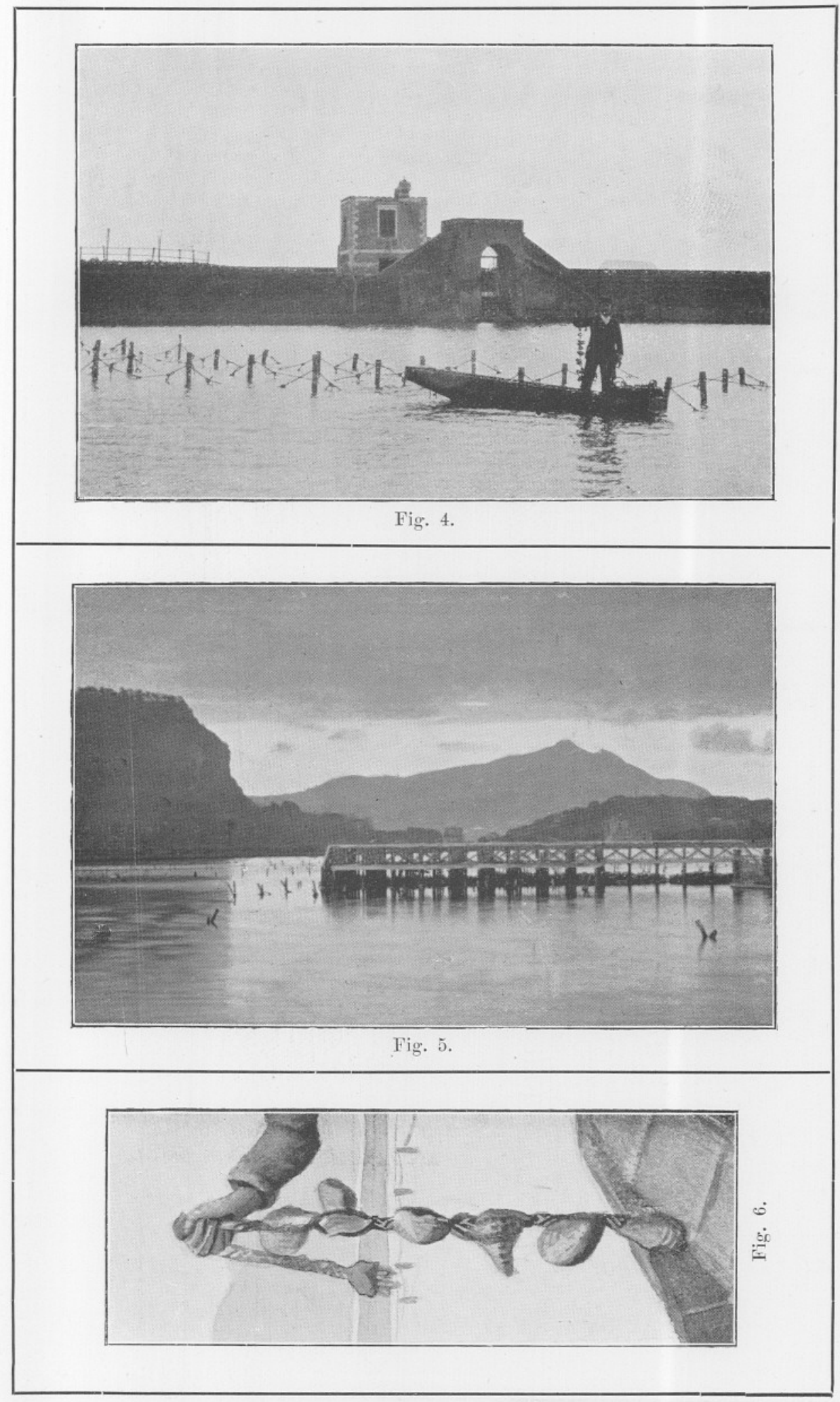




\section{EXPLANATION OF PLATE I.}

Illustrating Mr. R. T. Günther's Paper on "The Oyster Culture of the Ancient Romans."

Fig. 1.- Ostriaria beneath a bridge connecting the upper stories of two buildings, similar to those represented in Fig. 2. One oyster is shown attached to each rope. To the right is a pier. Piombino vase. After De Rossi.

Fig. 2.-OSTriaria and buildings near Baiae. Three oysters are attached to each rope. The ropes hang from a framework, as in Fig. 1. Borgiano vase. After De Rossi.

Fig. 3.-Glass vase. Museo Borgiano.

Fig. 4.-Oyster culture in Lucrine Lake. The man in the punt is shown holding up a rope of oysters (cf. Fig. 6), which he has just detached from the cross-ropes between the posts.

Fig. 5.-View of Lake Fusaro, showing the upper ends of the posts used to support the oysters. On the left is the steep profile of the Monte di Procida. The volcanic peak in the distance is Mont' Epomeo in Ischia.

Fig. 6.-Rope with oysters (pergolaro), showing mode of insertion between the strands. I am indebted to Mr. C. Hallett for this sketch from my photograph. 